\title{
The Perversity of Sexual-harassment Law Effects of Recent Court Rulings
}

BY DAVID SHERWYN, MICHAEL C. STURMAN, ZEV J. EIGEN, MICHAEL HEISE, AND JENN WÁLWYN

onsider the following situation.

The presidents of two chain restaurants are concerned about their potential liability due to sexual-harassment suits. Both presidents therefore ensure that their companies develop and enforce well-drafted policies against sexual harassment. The second president, hoping to provide even further protection for his organization, also provides sexual-harassment training for its managers and a toll-free number that allows employees to report harassment 24 hours per day.

Unfortunately, despite corporate policy, a night manager at each chain is engaged in sexually harassing behavior. Although the two employees affected by this behavior become quite upset, they initially fear reporting it. After some time, the employee at the second chain remembers the option of reporting the harassment through the toll-free number and calls to complain about the manager's behavior. The person who receives the call promises to investigate, and, indeed, the company does investigate and subsequently fires the manager. Three months later, the employees at both companies, both of whom have by this time quit their jobs, file charges of discrimination with the Equal Employment Opportunity Commission.

The president of the second chain restaurant refuses a reasonable settlement offer because he is confident that the company's training and toll-free reporting line, along

(C) 2001, CORNFI I UJNIVFRSITY with the fact that his firm fired the harasser, will absolve the company of liability. The president of the first company, on the other hand, is concerned that her firm did not have a toll-free hotline, that it did not train its employees well, and, moreover, that the harasser still works for the company. Company One decides to settle at any cost.

The question we pose for the reader is, Which president chose wisely regarding whether to settle their lawsuit? The best answer that we can propose is, neither one. According to current law, both presidents chose poorly, as we explain in this article. While the company that dismissed the manager based on the toll-free call may prevail, there remains a good chance that it will lose in court. On the other hand, the company that provided no training and no toll-free number is almost assured of victory.

The idea that an employer could protect itself from sexualharassment liability by failing to provide a sexual-harassment hot line or train employees is contrary to the intent of the law, and that is the "perversity" of sexual-harassment law to which we allude in the title of this article. The reason for this counter-intuitive possibility lies within the results of two Supreme Court rulings, namely, Burlington Industries v. Ellerth ${ }^{1}$ and Faragher $u$ Boca Raton. ${ }^{2}$ These holdings created numerous questions that could be answered only after lower courts interpreted the decisions in subsequent cases. This paper examines the progeny of Ellerth and Faragher, which constitute 109 sexual-harassment court cases decided after those two decisions. ${ }^{3}$ These rulings help illuminate the types of policy

\footnotetext{
1524 U.S. 775,118 S. Ct. 2275 (1998).

2524 U.S. 742, 118 S. Ct. 2257 (1998).
}

${ }^{3}$ This arricle is based on: David Sherwyn, Michael Heise, and Zev J. Eigen, “Don't Train Your Employees and Cancel Your '1-800' Harassment Hotline: An Empirical Examination and Correction of the Flaws in the Affirmative Defense to Sexual Harassment," Fordham Law Review, Vol. I.XIX, Number 4 (2001), pp. 1265-1304. 
and practice that successfully protected organizations from sexual-harassment liability in court cases. Before delving into a number of those 109 cases, however, we first provide some background established by prior sexual-harassment holdings.

\section{Sexual-harassment Rulings}

A detailed discussion of the history and development of sexual-harassment in the workplace exceeds this article's scope. It is important to note, however, that no federal statute expressly prohibits or even addresses sexual harassment in the workplace. Moreover, scholars generally agree that when enacting Title VII of the Civil Rights Act of 1964 (under which most sexualharassment cases are brought), Congress did not contemplate that the statute's prohibition against discrimination based on sex would create a cause of action for employees who were subjected to unwanted sexual advances without suffering any tangible loss. ${ }^{4}$ In fact, the origins of the legal prohibition against sexual harassment are generally attributed to Catherine MacKinnon.

MacKinnon coined the term sexual harassment and built the foundation of a cause of action in 1979, when she published the book Sexual Harassment of Working Women. ${ }^{5}$ MacKinnon defined sexual harassment in its broadest sense as the "unwanted imposition of sexual requirements in the context of a relationship of unequal power." The influence of her work on both courts and scholars was swift and profound. ${ }^{7}$

\footnotetext{
${ }^{4}$ For example, see: Gillian Hadfield, "Kational Women: A Test for Sex-based Harassment," 83 California Law Rev, 1151, 1166 (1995), which discusses the Supreme Court's interpretation of Congressional intent embodied in Title VII's protection against sexual harassment in Meritor Bank FSB v. Vinson, and Michelle Angelone, "Same-sex Harassment Claims Under Tirle VII: Quick v. Donaldson Co. Breathes New Life into the Post-Garcia State of the Law," Journal of Law and Public Policy, Vol. 9, No. 61 (1997), pp. 76-79, which discusses several courts' interpretations of Congressional intent underlying sexual discrimination. Tangible losses occur when there is a material change in employment, such as termination, failure to promote, demotion, or a change in benefits. See Ellerth at 2268-2269.
}

5 Catherine Mackinnon, Sexual Marassment of Working Women. $A$ Case of Sex Discrimination (New Haven, Yale University Press, 1979). See also: Kathryn Abrams, "The New Jurisprudence of Sexual Harassment," 83 Cornell Law Review, 1169 (1998), which discusses MacKinnon's influential role in the development of sexual-discrimination law.

${ }^{6} I d$. at 1 . See also: Louis P. DiLorenzo and Laura H. Harshbarger, "Employer Liability for Supervisor Harassment After Ellerth and Faragher," Duke Journal of Gender Law and Policy, Vol. 6, No. 3 (1999), pp. 3-26.

${ }^{7}$ For example, see: Kristine A. Littleton, "Feminist Jurisprudence: The Difference Merhod Makes," 41 Stanford Law Review, 751 (1989), which reviews MacKinnon's work and discusses its profound influence on legal doctrine and practice.
In 1980 the Equal Employment Opportunity Commission (EEOC) expanded its guidelines, "Discrimination because of Sex under Title VII," to include sexual harassment. ${ }^{8}$ After the EEOC published its guidelines, courts routinely held that sexual harassment by means of a hostile environment did, in fact, create a cause of action. ${ }^{9}$ In 1986, in Meritor Savings Bank v. Vinson, the U.S. Supreme Court put to rest any lingering questions concerning the legal efficacy of MacKinnon's hostile-environment theory. ${ }^{10}$ Specifically, the court ruled that sexual harassment constituted a legal cause of action that violated Title VII and that sexual harassment comes in two forms: (1) quid pro quo ${ }^{11}$ and (2) hostile environment. ${ }^{12}$ Unfortunately, even though the Meritor ruling established the unlawfulness of sexual harassment, its opinion left open several questions regarding employers' vicarious liability for their supervisors' actions. Subsequent cases have explored this matter of employers' liability.

New standards. Considerable discussion about sexual harassment ensued in the years since Meritor. Commentators have addressed why sexual harassment occurs, the resulting harm, and how courts should apply standards set forth in

${ }^{8}$ The EEOC guidelines define quid pro quo harassment as " $U n$ welcome sexual advances, requests for sexual favors, and other verbal or physical conduct of a sexual nature... when (1) submission to such conduct is made either explicitly or implicitly a term or condition of an individual's employment, [or] (2) submission to or rejection of such conduct by an individual is used as the basis for employment decisions affecting such individual...." 29 C.F.R. $\$ 1604.11$ (a)(1985).

' See: Henson v. Dundee, 682 F.2d 897 (1982) at 902, which states: "Sexual harassment which creates a hostile or offensive environment for members of one sex is every bit the arbitrary barrier to sexual equality at the workplace that racial harassmenr is to racial equality. Surely, a requirement that a man or woman run a gauntlet of sexual abuse in return for the privilege of being allowed to work and make a living can be as demcaning and disconcerting as the harshest of racial epitlets." See also: Katz v. Dole, 709 F.2d 251, 254-255 (CA4 1983); Bundy u. Jackson, 205 U. S. App. D. C., at 444-454, 641 F.2d, at 934-944; and Zabkowicz v. West Bend Co., 589 H.Supp. 780 (E.D. Wis. 1984).

${ }^{10} 477$ U.S. 57 (1986), aff'g sub nom Vinson v. Taylor, 243 U.S. App. D.C. 323, 753 F.2d 141 (1985).

1 Quid pro quo harassment is defined as predicating wages, hours, or other terms and conditions of employment on the acquiescence to unwanted sexual favors. Quid pro quo harassment occurs when, for example, an employer or its supervisors states, "sleep with me or you are fired." In Ellerth the Supreme Court clarified quid pro quo cases by holding that employees had to prove that they suffered a tangible loss to make the claim.

${ }^{12}$ Hostile-environment discrimination is defined as an employee's being forced to endure unwelcome sexual conduct in the workplace sufficiently severe or pervasive "to alter the conditions of [the victim's] employment and create an abusive working environment."
The fallout from two 1998 Supreme Court rulings is a tangled interpretation of how to prevent sexualharassment liability. The short answer: do the right thing. 
Meritor and its progeny. ${ }^{13}$ In its 1998 term the Supreme Court articulated new standards for employer liability in sexual-harassment cases. Those rulings, Burlington Industries v. Ellerth and Faragher v. Boca Raton, attempted to clarify Meritor, but left many questions unanswered.

In the Ellerth and Faragher opinions, the Supreme Court held that employers are liable for actions of supervisors who engage in either quid pro quo sexual harassment or hostileenvironment sexual harassment, regardless of whether the employers knew or should have known of the alleged conduct. Under Ellerth and Faragher employers cannot escape liability for situations where there was a tangible loss. If there were no tangible losses, however, employers can avoid liability for harassment by their employees by satisfying a newly created affirmative defense. That defense involves two elements. Employers must prove that (1) the employer "exercised reasonable care to prevent and promptly correct any sexually harassing behavior" and (2) the plaintiff "unreasonably failed to take advantage of any preventive or corrective opportunities provided by the employer or to otherwise avoid harm."14

New confusion. Reaction to the Supreme Court's articulation of this affirmative defense was swift and heared. ${ }^{15}$ Almost all commentators agreed that the holdings were ambiguous because neither Ellerth nor Faragher contained a definition of reasonable care. Although the af-

\footnotetext{
${ }^{13}$ Abrams, op. cit.

${ }^{14}$ The U.S. Supreme Court explained this defense by asserting "[p] roof that an employer had promulgared an anti-harassment policy with complaint procedure is not necessary in every instance as a matter of law..." The Court did not, however, explain how an employer could satisfy this burden without a policy. With regard to the employee's actions, the Court was again less than exact: "While proof that an employee failed to fulfill the corresponding obligation of reasonable care to avoid harm is not limited to showing any unreasonable failure to use any complaint procedure provided by the employer, a demonstration of such failure will normally suffice to satisfy the employer's burden under the second element of the defense." Ellerth, 118 S.Ct. at 10.

${ }^{15}$ Numerous articles came in the wake of the courr's decision discussing the implications of the ruling. For example, see: Estelle D. Franklin, "Maneuvering Through the Labyrinth: The Employers' Paradox in Responding to Hostile Environment Scxual Harassment $-\Lambda$ Proposed Way Out," 4 Fordham Law Review, 1517 (1999); B. Glenn George, "Employer Liability for Sexual Harassment: The Buck Stops Where?," 34 Wake Forest Law Review, 1 (1999); Steven H. Aden, "Harm in Asking: A Reply to Eugene Scalia and an Analysis of the Paradigm Shift in the Supreme Court's Title VII Sexual Harassment Jurisprudence," 8 Temple Policy and Civil Rights Law Review, 477 (1999), and Louis P. DiLorenzo and Laura H. Harshbarger, "Employer Liability for Supervisor Harassment After Ellerth and Faragher," Duke Journal of Gender Law and Policy, Vol. 6, No. 3 (1999).
}

firmative defense's first prong pivots on this matter, it is unclear what constitutes reasonable care in the employment context. Some scholars, lawyers, and commentators argue, for instance, that the fact that an employer merely has an antiharassment policy is not sufficient. Instead, they propose that to exercise reasonable care employers need to take additional steps, such as training for employees and supervisors. ${ }^{16}$

Land of opportunity? The second prong's requirements are similarly unclear. The Supreme Court did not articulate circumstances under which it would be unreasonable for an employee to ignore the opportunities created by the employer or otherwise avoid harm. To some, this lack of a clearly defined and enforceable standard is yet another barrier to employers' prevailing at summary judgment. ${ }^{17}$ Such a prediction is

\footnotetext{
${ }^{16}$ See: Paul Buchanan and Courtney W. Wiswall, "The Evolving Understanding of Workplace Harassment and Employer Liability: Implications of Recent Supreme Court Decisions Under Title VII," 34 Wake Forest Law Review, 55 (1999) at 64, who commented: "Of course, courts will likely require more than the mere existence of a well drafted and effectively promulgated written policy to support a finding that an employer exercised reasonable care to prevent sexually harassing behavior. Employers should regularly conduct training to educate employees about harassment and company policies. Training of supervisors is particularly important given the Supreme Court's clear mandate that employers may be held vicariously liable for the conduct of supervisors. To ensure that the employer derives maximum benefit from these efforts, records should be kept that make clear who has received training and when." See also: DiLorenzo and Harshbarger, pp. 19-20, who wrote: "The recent rulings suggest that training rank and file employees in the use of the complaint procedure may be as critical as training supervisors to refrain from engaging in harassing conduct or properly responding to complaints or other notice of inappropriate conduct. An employer invoking the affirmative defense must be prepared to show that it acted reasonably to prevent and correct harassment and that the plaintiff failed to act reasonably to prevent, correct, or otherwise avoid the harassing conduct. An employer who demonstrates that all employees were made aware that the employer had a policy and were also fully informed as to the procedure for reporting harassment is far more likely to successfully demonstrate its own reasonableness in preventing or correcting harassing behavior. Moreover, an employer who actively trains all employees in the use of the policy, and thereby educates its employees in the importance of their role in preventing or correcting the prohibited bchavior will undoubtedly have a per suasive argument that an employee's failure to invoke the reporting procedure was unreasonable, and, therefore, establish irs affirmarive burden."

${ }^{17}$ See: Theresa M. Beiner, "The Misuse of Summary Judgment in Hostile Environment Cases," 34 Wake Forest Law Review, 71,73 n. 10 (1999), which argues that federal courts are misusing summary judgment in hostile-environment cases brought under Title VII; and Anne Lawton, "The Emperor's New Clothes: How the Academy Deals with Sexual Harassment," 11 Yale Journal of Law or Feminism, 75 (1999), which predicts that leaving the determination of reasonable behavior on the parts of both employers and employees to the lower courts will make it more difficult for employers to win on summaryjudgment motions.
} 
based on two separate theories. First, some scholars argue that a court will let a jury decide whether it is reasonable for an employee to fail to report sexual harassment because of the employee's fear of repercussions. ${ }^{18}$ Second, others argue that employees cannot only avoid summary judgment, but can defeat the defense and make the employer liable if they report the alleged harassment. ${ }^{19}$ Indeed, Justice Clarence Thomas's dissent in Ellerth advances the latter proposition. Justice Thomas reads the majority's opinions as holding that an employee who reports sexual harassment cannot, as a matter of law, be found to have unreasonably failed to take advantage of any preventive or corrective opportunities provided by the employer or to otherwise avoid harm..$^{20}$ Thus, according to Justice Thomas, an employer is liable for sexual harassment if and when the employee reports (assuming the complaint is genuine). ${ }^{21}$ Glenn George, on the other hand, argues that an employee's Title VII claim will fail if the employer deals promptly and effectively with a victim's complaint. ${ }^{22}$ With few actual cases to analyze, early scholarly commentary was essentially speculative. ${ }^{23}$

Early articles assessing the new affirmative defense typically involved an analysis of a limited number of cases and a substantial amount of hypothesizing about what future courts would do. Specifically, many commentators argued that

\footnotetext{
${ }^{18}$ See: Dominic Bencivenga, "Looking for Guidance: High Court Rulings Leave Key Terms Undefined," New York Law Journal, July 2, 1998, at 5, which discusses how practicing attorneys think that the affirmative defense is not clear enough because the language is ambiguous and the case law provides little guidance.

${ }^{19}$ Shira A. Scheindlin and John Elofson, "Judges, Juries, and Sexual Harassment," 17 Yale Law and Policy Review, 813 (1999), which notes that defendants should rarely prevail in summary judgment motions in sexual-harassment cases; and Lawton, op. cit.

${ }^{20}$ Ellerth, 524 U.S. at 767 (Thomas, C., dissenting).

${ }^{21}$ Id. at 767-768; also see: Buchanan and Wiswall, 64, which argues that summary-judgment decisions in favor of employers may decrease; and Francis Achampong, "Employer Liability for Hostile Environment Sexual Harassment by a Supervisor: A Critical Assessment of the Supreme Court's New Vicarious Liability Standard," 28 Syracuse University Law Review, 45, 67 (1998).

${ }^{22}$ See: George, p. 21.

${ }^{23}$ For example, see: Robert Belton, "Employment Law: A Review of the 1997 Term Decisions of the Supreme Court," Employee Rights and Employment Policy Journal, 267, 280-289, which discusses several questions left unanswered by Ellerth and Faragher.
}

(1) employers would not prevail in summaryjudgment motions; (2) employees who reported would always prevail; (3) employees who did not report would survive summary judgment; and (4) employers would have to do much more than have a sexual-harassment policy to exercise reasonable care. ${ }^{24}$

\section{We found that employers are still able to prevail in summary-judgment motions by using the affirmative defense.}

Now that enough time has passed, we can analyze a group of decisions and explore how courts have applied the affirmative defense. This article analyzes the outcome of 109 motions for summary judgment filed since June 1998, in which employers argued that a hostile-environment case should be dismissed because the employer satisfied, as a matter of law, the affirmative defense. ${ }^{25}$ We focus on how courts have analyzed the "reasonable" standard in both prongs. The examination of these cases provides the opportunity to test past conjecture and describe how courts have implemented the Ellerth and Faragher rulings.

\section{No Foregone Conclusions}

Our analysis of summary-judgment motions yielded interesting results. First, we found that employers are still able to prevail in summaryjudgment motions. Employers won in 38 of the 72 cases filed by January 2000 , a rate similar to that achieved by employers prior to the new holdings. ${ }^{26}$ With evidence showing that employers can satisfy the affirmative defense, we thus delve into

\footnotetext{
${ }^{24}$ See: Franklin, at $1548-1555$.

${ }^{25}$ For a discussion of possible motivations for the courts' decision to grant summary-judgment mocions, see: Beiner, at 71 and 73 , which identifies a desire to reduce a bulging caseload of hostile-environment cases.

${ }^{26}$ See: George, at 17-18, who predicts difficulty for employers attempting to establish the affirmative defense when plaintiffs can posic facrs alleging fear of retaliation as an underlying justification for failing to report the harassing behavior promptly; and Jonathan W. Dion, "Putting Employers on the Defense: The Supreme Court Develops a Consistent Standard Regarding an Employer's Liability for a Supervisor's Hostile Work Environment Sexual Harassment," 34 Wake Forest Law Review 199, $221-222$ (1999).
} 
each of the three areas that commentators have suggested should have prevented such success. Specifically, we examine (1) what courts required to constitute reasonable care, (2) how courts have ruled when employees failed to report harassment, and (3) how courts have ruled when employees did report harassment.

\section{At this time the law is reasonably clear:}

\section{a company's so-called "good policy" constitutes reasonable care.}

or fail to investigate). We did find one case that implied that an employer might need more than just a policy, but the court did not base its holding on the matter. ${ }^{28}$ Thus, at this time, the law is reasonably clear: a so-called "good policy" constitutes reasonable care.

\section{Employees Who Do Not Report}

In contrast to the predictions and the policy arguments regarding employees' failure to report, all 20 employees who failed to report harassment after their employer satisfied the first prong of the test were found to be unreasonable by a court. Based on those results, it seems that failure to reporr (and then going to courr) is per se unreasonable. Supporting this inference, for example, the court in Kohler v. Inter-Tel Technologies without further explanation held that an employee who failed to report was unreasonable in seeking a judgment. ${ }^{29}$

Reasonable failure. Language in other cases, however, implies that an employee could defeat the good-policy defense by "reasonably" failing to report. In Shaw v. AutoZone, Inc., the plaintiff argued that she did not complain about being harassed because "she didn't feel comfortable enough with anyone at AutoZone to speak with them about the... conduct." ${ }^{30}$ In finding such fear unreasonable, the court stated: "We conclude that an employee's subjective fears of confrontation, unpleasantness, or retaliation do not elevate the employee's duties under Ellerth to alert the employer to the allegedly hostile environment." ${ }^{31}$

One can infer from the court's holding that if subjective evidence is not enough to justify failing to report then objective evidence would, in fact, create a jury question.

The court's ruling in Kibby v. Chief Auto Parts, which involved more than one plaintiff, makes such an inference stronger. ${ }^{32}$ There, the court found the employees' actions unreasonable becausc the plaintiffs failed to identify "any material fact issue regarding their failure to use the process set up by Chief to protect them from employer changed.

In fact, every court to rule on that issue held that the employer had exercised reasonable care when it had a "good policy" and did nor otherwise mishandle a sexual-harassment complaint (i.e., the employer did not ignore the complaint

\footnotetext{
${ }^{27}$ For example, see: Perry v. Harris Chernin, Inc, 126 F.3d 1010, 1013 (7th Cir. 1997); Nash v. Electrospace Sys., Inc., 9 F.3d 401, 404 (5th Cir. 1993); Burns v. McGregor Elec. Indus., 955 F.2d 559, 564 (8th Cir. 1992); and Swentek v. USAIR, Inc., 830 F.2d 552, 558 (4th Cir. 1987).
}

${ }^{28}$ See: Lancaster $v$ Sheffler Enterprises, 19 F. Supp. 2d 1000, 1003 (W.D. Mo. 1998), where the court, in dicta, stated that reasonable care required more than a policy.

${ }^{29}$ N.D. Ca. 1999, 1999 U.S. Dist. LEXIS 5425. at 15-16. The court explained, “... [p]laintiff acted unreasonably by never rcporting any harassment and choosing not to cooperate in Inter-Tel's investigation."

${ }^{30} 180$ F. $3 d 806$ (7th Cir. 1999), ar 813

${ }^{31} \mathrm{Id}$.
${ }^{32}$ N.D. Tex. 1999, 1999 U.S. Dist. LEXIS 2894. 
sexual harassment or to show lack of reasonable care." ${ }^{33}$ Again, this case implies that certain material facts could justify the plaintiffs' failure to report. This is important because it is likely that plaintiffs' lawyers, relying on predictions from the media and a general rule that questions of reasonableness go to juries, did not create a record of the type of factual disputes that would satisfy the courts. Now, however, plaintiffs' lawyers will know that to get to a jury a plaintiff must provide objective evidence to prove that it was reasonable not to report.

\section{Employees Who Do Report}

While the effect of not reporting may be clear, the outcomes of cases that involve employees' filing a complaint are at the moment both unclear and hard to resolve under the current articulation of the defense. As stated above, Justice Thomas's dissent argues that an employer cannot possibly prevail in a case in which the employee reported the harassment because he or she could not have unreasonably failed to take advantage of any preventive or corrective opportunities provided by the employer. ${ }^{34}$

Some courts have agreed with Justice Thomas by applying the defense mechanically and holding employers liable even when the company did all that it could have done. For example, in Moore v. Sam's Club, the plaintiff alleged that the comanager of the store where the plaintiff worked harassed her. ${ }^{35}$ The conduct occurred in either late March or early April, and the plaintiff complained on April 25. On May 1, she was asked to provide a detailed statement. The company then investigated and suspended the harasser on May 3 . The suspension ended on June 15, and the harasser was demoted and transferred. The plaintiff then requested a transfer from New York to Florida, which the company granted. The plaintiff moved to Florida, but did not report to work. Instead, she sued.

Surprising loss. In addressing the summaryjudgment motion, the court first held that Sam's Club had exercised reasonable care in both its policy and response to the complaint. The court then held, however, that Sam's Club could not prevail on the second prong of defense because

\footnotetext{
${ }^{33} \mathrm{Id}$. at 20 .

${ }^{34}$ Ellerth, 118 S. Ct. 2257 at 2274.

3555 F. Supp. $2 d 177$ (S.D. N.Y. 1999). At trial the plaintiff also alleged that she was raped. The company was unaware of this allegation when it meted out its discipline.
}

the plaintiff took full advantage of the preventative measures provided and had therefore not acted unreasonably. ${ }^{36}$ Thus, Sam's Club did everything it could have, but lost because the plaintiff also acted appropriately.

To some, the Sam's Club case outcome makes sense, on the argument that the employee suffered a horrible experience and was compensated for it. The problem with that argument is that the employer's liability is based on the employee's actions and not that of the company. This tortuous logic can lead to inconsistent and sometimes inexplicable outcomes that actually could create a perverse incentive for employers. Because employers are best off when employees fail to report, employers should exercise the minimal carc ncccssary to satisfy the defense's first prong and then hope that their employees do not report. Thus, this argument goes, employers who wish to avoid liability should not train their employees and should not provide easy reporting mechanisms such as harassment hotlines.

Fortunately, the majority of courts interpreting the affirmative defense refuses to hold employers who responded properly to complaints of sexual harassment liable for their supervisors' actions. Instead, most courts wish to reward employers for doing what they should do to prevent and correct harassment. Moreover, courts do not want their holdings to be based solely on whether the employer fortuitously employed individuals who failed to act "reasonably" by not reporting. Thus, judges are drafting resultsoriented rulings that are based exclusively on the employer's actions (i.e., prevention and response to harassment).

Awkward position. Still, the courts need a way to address the fact that the second prong of the defense focuses on the employee's conduct. In other words, this logic dictates that judges must find an employee unreasonablc to hold for an employer. Judges do this in one of three ways. They (1) create new law by holding that the defense does not apply when the employee reports, (2) find the employee's report unreasonable because it is untimely, or (3) find the employee's report unreasonable because the employee reported to the "wrong" person. For

\footnotetext{
${ }^{36}$ Id. at 192-93. The court noted that the second prong of the Ellerth/Faragher defense "does not apply here." The court also noted that "[i]t is thus unclear how the Ellerth/Faragher defense, on its own terms, would apply here" since the factual scenario of those cases are distinct from those in Moore.
} 
example, in Indest v. Freeman Decorating, Inc., the Fifth Circuit distinguished Ellerth and Faragher from cases in which an employee uses an employer's policies and procedures and held that the affirmative defense created by the Supreme Court does not apply in such situations. ${ }^{37}$ The court then created what essentially amounts

an employer is not automatically liable for the actions of its supervisors.

Timeliness counts. Indest supports what could be seen as a departure from Ellerth and Faragher by arguing that a quick report and quick response will prevent the conduct from being severe or pervasive enough to be actionable. This argument may be true, but the point of the holding is the timeliness of the employer's response rather than the nature of the harasser's conduct. The Indest court did not hold that the conduct at issue was not severe or pervasive. Instead, the court noted that it need not address that matter because the company promptly responded to the harassment complaint and consequently satisfied

to a new defense for employers. That is, employers who swiftly respond to complaints of sexual harassment are not liable for the actions of their supervisors. Applying this standard, the Fifth Circuit held:

Because she [the plaintiff] promptly complained of Arnaudet's harassing conduct and because the company promptly responded, disciplined Arnaudet appropriately, and stopped the harassment, the district court properly granted judgment as a matter of law to [defendant] Freeman. Even if a hostile-work-environment claim had been stated, which is dubious, Freeman's prompt remedial response relieves it of Title VII vicarious liability. ${ }^{38}$

Despite what seems to be a rejection of Ellerth and Faragher, the Indest court states that it relied on the principles of these two cases along with the Meritor decision to formulate its holding. The court explaincd that when a plaintiff promptly complains, both the employee and the employer could thwart harassment before it becomes actionable. This result, according to the court, effectuates the purposes of Title VII because the employee receives the benefit of having the harassment stopped and the employer is rewarded for its swift response. Moreover, this standard comports with Meritor, which held that

\footnotetext{
${ }^{37}$ Indest $v$. Freeman Decorating, Inc., 164 F.3d 258 (5th Cir 1999) at 265, which notes that, "Ellerth and Faragher do not, however, directly speak to the circumstances before us, a case in which the plaintiff quickly resorted to Freeman's policy and grievance procedure against sexual harassment, and the employer took prompt remedial action."

${ }^{38}$ Id. at 267
}

the affirmative defense. Thus, in the Fifth Circuit at least, an employer who exercises reasonable care in responding to a complaint of sexual harassment will be able to prevail on the affirmative defense and avoid liability even if the conduct was severe or pervasive. Evidently, the court in Indest did not want to find against the "good actor" employer, and so it distinguished the case from Ellerth and Faragher.

At least one court may have followed the Indest standard. In Hammonds v. Fitzgerald's Mississippi, the plaintiff was subjected to unwanted sexual advances by her supervisor but failed to report or use any of the remedies provided by the defendant employer's sexualharassment policy. ${ }^{39}$ Nine months later the same supervisor raped her, and she reported that incident three weeks later. After the plaintiff reported the rape, the defendant thoroughly investigated the incident and the harasser resigned under threat of termination. In granting the defendant's summary-judgment motion, the court set forth two different rationales that could form the basis for the holding: (1) the employer's response and (2) the fact that the employee did not report the conduct that preceded the rape.

The court did not, however, state which rationale was dispositive. If it relied on the employer's response, then the court applied the rationale set forth in Indest. While this may be problematic to some, it is not nearly as objectionable as relying on the employee's "late" report. As we discuss below, judging the report is an unacceptable method for operationalizing the

\footnotetext{
${ }^{39} 1$ y9y U.S. Dist. LEXIS 19548.
} 
defense. Unfortunately, the majority of courts that were faced with instances in which a supervisor harassed an employee, the employee complained, and the company responded properly have, in fact, taken what we consider to be an undesirable approach of holding for the employer by analyzing the employee's report and finding it unreasonable because it was untimely or somehow defective. ${ }^{40}$ We discuss below a number of those cases and explain why this is an undesirable approach.

In 12 cases from our sample, a plaintiff was found to be unreasonable because she delayed in reporting the harassment. ${ }^{41}$ In some cases there was a delay of one year or more between the first harassing action and the report. ${ }^{42}$ In other cases, however, the delay was a matter of months or even weeks. For example, in Nuris Guerra v. Editorial Televisa, the plaintiff, who began working on May 26, 1996, was harassed every day from either her first or second week of work until she complained on June 20, 1996. ${ }^{43}$ In dismissing the case, the court held that the delay combined with the employer's prompt and proper response satisfied the second prong of the defense. Similarly, in Mirakhorli v. DFW Management Company, it was unclear whether the harassment began two or eight months before the plaintiff complained. ${ }^{44}$ The court was unconcerned with the discrepancy, though, because it found a delay of either two or eight months unreasonable as a matter of law. Finally, in Dedner v. State of Oklaboma the plaintiff waited three months to report the harassment because she did not think the employer's procedures would be effective and because she thought the supervisor would not stop the harassing behavior. Again, the court

\footnotetext{
40 Reports are deemed defective because they are either untimely or reported to the wrong party. A defective complaint, according to numerous holdings, equals an unreasonable employee.

${ }^{41}$ It must be noted that in each of these cases the employer responded with reasonable care according to the court.

${ }^{42}$ For example, see Hetreed v. Allstate Insurance Co., N.D. Il. 1999, 1999 U.S. Dist. LEXIS 7219 (a four-year delay).

43 S.D. Fl. (1999), 1999 U.S. Dist. LEXIS 10082.

${ }^{44}$ N.D. Tex. 1999, 1999 U.S. Dist. LEXIS 9344.
}

found the delay unreasonable and granted summary judgment. ${ }^{45}$

Other complications. Delay is not the only rationale that courts use for finding employees who report harassment to be unreasonable. Several decisions held that reporting to the wrong party constitutes an unreasonable failure to take
When a plaintiff promptly complains, both the employee and the employer may be able to thwart harassment before it becomes actionable. In those cases, the employee receives the benefit of having the harassment stopped and the employer is rewarded for its swift response. advantage of the employer's policies and procedures. In Decesare v. Nat'l R.R. Passenger Corp., the plaintiff complained by filing a grievance with her union instead of using the company's procedures. The court found this unreasonable. ${ }^{46}$ In Masson v. Sch. Bd. of Dade County the court dismissed the case of an employee who filed multiple complaints with people who were not

\footnotetext{
4542 F. Supp. 2d 1254 (E.D. Okla. 1999). While a delay may be unreasonable as a matter of law to some courts, other summary-judgment motions have been denied so that a jury could decide whether the plaintiffs' delay was reasonable. See: Fall v. Indiana Univ., 12 F. Supp. 2d 870, 881 (N.D. Ind. 1998), which involved a three-month delay; and Watts $v$. Kroger, 170 F. 3d 505, 508 (5th Cir. 1999), in which the delay was one and a half months.

${ }^{46}$ E.D. Pa. 1999,1999 U.S. Dist. 7560, at *19*20. The court noted that the plaintiff acknowledged that the defendant issucd a paper to evcrybody regarding its sexual-harassment policy, that she made no attempt to look for any personnel manual or policies regarding sexual harassment, and that she consciously opted not to look for any such policy because she preferred to go through the union. The court held that this conscious disregard for preventive or corrective opportunities provided by the employer was unreasonable. See, however: Watts v. Kroger, 170 F. 3d 505, 508 (5th Cir. 1999), at 510-511, where reporting to the union was considered reasonable as a matter of law.
} 
designated to hear sexual-harassment complaints. ${ }^{47}$ (Moreover, Mason complained of being replaced, not of being sexually harassed.) However, in Powell v. Morris the court held that it was for a jury to decide whether a report that did not follow procedures was unreasonable. ${ }^{48}$

interpreting them suggests a difficult situation for employers. They could be held liable even when they do all that they can to prevent sexual harassment but the employee reports harassment. On the other hand, they could easily be liability free when they do a lesser job of preventing harassment but happen to be fortuitous enough to employ someone who fails to take reasonable steps to report his or her claim. Thus, the Ellerth and Faragher rulings and their progeny leave employers who wish to avoid liability with some uncomfortable guidance on how to do so.

The current legal environment encourages employers to develop anti-sexual-harassment practices

A slippery slope. Judging the reasonableness of a complainant's actions creates numerous problems. First, we see little sense in holding that an employee is unreasonable for waiting several weeks to report harassment. Pursuing a sexualharassment complaint can be difficult. Regardless of the company's procedures, employees may wonder whether they are being overly sensitive by misinterpreting innocent banter or whether they can resolve the issue without the angst and difficulty associated with bringing a formal complaint. Although the Indest court points out that early complaints may nip harassment before it blooms to an unlawful level and, therefore, such early non-litigation activity should be encouraged, we believe that early reporting of claims should not be required. ${ }^{49}$ Employees should not have to endure the stress of what results in, for all intents and purposes, a two-month statute of limitations on harassment. Because employees should and do take the act of reporting harassment seriously, they may need time to determine all relevant issues. A short statute of limitations will force employees to complain of harassment before they are sure that the conduct is or will soon be unlawful or even inappropriate. This could well lead to more complaints that may be dismissed as harmless.

Uncomfortable guidance. The U.S. Supreme Court arguably created a paradoxical situation when it created the affirmative defense. The language of the two rulings and some of the cases

\footnotetext{
4736 F. Supp. 2d 1354 (S.D. Fl. 1999).

${ }_{48} 37$ F. Supp. 2d 1011 (S.D. Ohio 1999).

${ }^{49}$ Indest, at 266.
}

limited only to enacring and disseminating an anti-harassment policy. To minimize legal exposure, employers ironically should not engage in or should eliminate preventative efforts such as extensive and expensive sexual-harassmentsensitivity training and, especially, harassmentreporting hotlines. Although numerous cases support the notion that courts do not want to punish employers who make significant efforts to prevent and correct sexual harassment, the statistics indicate that employers are actually safer when the employee somehow fails to report the harassment. Thus, while training and toll-free hotlines may be effective at reducing incidences of harassment, they could potentially render unavailable an affirmative defense because such measures encourage employees to report.

\section{What This Means for Employers}

The analysis of the first 109 summary-judgment motions filed under the Ellerth and Faragher standard provides employers with answers, questions, and arguments. The answers seem clear enough. First, to exercise reasonable care in preventing harassment an employer needs a "good" harassment policy. This does not mean, however, that you necessarily need to train employees or to develop a harassment hotline. Second, employees who do not report harassment will be found legally unreasonable unless there is objective evidence that supports their fear of reporting. This is a consideration for employers who are deciding whether to settle or to litigate a case. Third, employers can win summary-judgment motions in cases where the employee reported if the report was untimely or defective in some other manner. Finally, to avoid liability, employers 
should exercise minimal care and hope the employee does not report-or so it seems.

The high-hopes defense. The questions remaining after our analysis are derived from the last factor, which involves the hope that employees won't report harassment. First, should your company do less than all it can do to prevent harassment because so doing will result in a better defense? This is both a humanresources and an ethical issue. Second, is avoiding liability the best method for reducing the cost of sexual-harassment lawsuits? If, for instance, training and harassment hotlines reduce the number of lawsuits filcd, cmploycrs who encourage reporting harassment may be able to stay out of court altogether by resolving matters well before a lawsuit is filed. Such scenarios, which remain private and beyond our scrutiny, may lead one to conclude that a full-fledged war on harassment is the best way to reduce costs even if it does result in the potential for an adverse jury verdict. Further research is needed to see whether this hypothesis is true.

Our study produces an argument that may absolve an employer from liability when the employer exercises reasonable care to prevent and correct harassment and the employee does not unreasonably fail to report. We contend that in cases in which the employee reports harassment, Ellerth and Faragher do not apply. Instead, we suggest a new standard for such situations, that simply being the first prong of the defense, namely, to establish whether the employer exercised reasonable care to prevent and correct harassment. Below, we explain how employers can present this argument to courts in such cases.

Proper actions. As the Indest court noted, in both Ellerth and Faragher the employees did not report the harassment to their employers before they quit their jobs. ${ }^{50}$ Moreover, neither opinion directly addresses or even alludes to the applicability of the defense when the employee does in fact report. ${ }^{51}$ Thus, because neither Ellerth nor

\footnotetext{
${ }^{50}$ See: $l d$ at 265 .

${ }^{51}$ Justice Thomas's Ellerth dissent, however, does address this issue and argues that in such cases the employer would lose. See: Ellerth, 524 U.S. at 773 (Thomas, C. dissenting).
}

Faragher applies the two-prong affirmative defense in a situation where the employee reported, we see no reason for lower courts to be bound by those decisions in such circumstances. Accordingly, lower courts are free to apply a standard that best effectuates the purposes of Title VII and 
and procedures that help achieve this goal. We contend that the defense should not apply to cases in which the plaintiff did report because (1) the court would never have made a holding that creates perverse incentives that compromise the very outcome that the court seeks to encourage, and (2) the logical extension of such a holding contradicts the opinions in the two cases.

In Faragher the employer had a policy, but did not disseminate it. ${ }^{52}$ The Supreme Court held that this failure prevented the employer from proving both that it exercised reasonable care and that the plaintiff was unreasonable. ${ }^{53}$ In Ellerth, by contrast, the company had a policy and disseminated it. ${ }^{54}$ Despire this fact, the plaintiff failed to report the harassment. ${ }^{55}$ According to the vast majority of lower courts that applied the affirmative defense, those two facts would result in satisfaction of the defense and dismissal of the case. The Supreme Court did not, however, dismiss Ellerth's case. Instead, it remanded the case so that the lower court could determine whether the employer's policy constituted reasonable care and whether the plaintiff's failure to report was unreasonable.

The fact that the case was remanded suggests that the majority of courts have misinterpreted the defense by holding that the existence of a policy and the failure to report amount to a victory for employers as a matter of law. Instead, this holding implies (1) that the first prong of the affirmative defense may require more than the mere existence of a policy, and (2) that employees who do not report may not always be unreasonable. If this is true, our reading of the Supreme Court's opinions makes sense. The Court developed this defense for situations in which an employee did not report, while at the same time the Court did not contemplate a situation in which the plaintiff-employee had, in fact, reported. Accordingly, lower courts are free to devclop a new defense that cffectuates the purposes of both the discrimination laws and the Ellerth and Faragher defense. The standard proposed here does just that.

\footnotetext{
${ }^{52}$ Faragher, 524 U.S. at $775,782$.

${ }^{53} \mathrm{Id}$. at 808 .

${ }^{54}$ Ellerth, 524 U.S. at 748.

${ }^{55}$ Id.
}

At this time, we are not aware of any court that has ruled on the argument set forth above. We cannot, therefore, provide any authority to support its efficacy. If, however, an employer were in the situation where (1) in addition to its policy it had exercised other efforts to prevent harassment, (2) the employee had reported harassment, and (3) the employer responded properly, this argument might be the best and perhaps only chance to avoid being held liable.

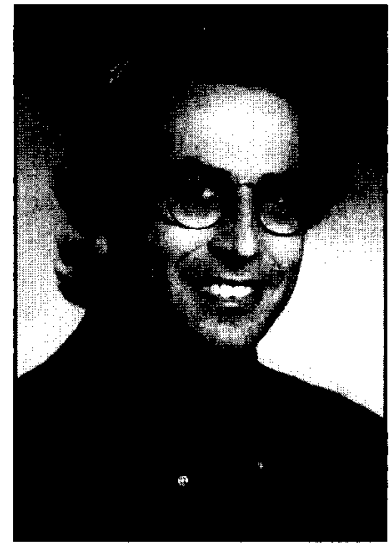

David Sherwyn, J.D.

(pictured), is an assistant professor of law at the Cornell University School of Hotel Administration (dss18@corneli.edu). where Michael C. Sturman, Ph.D., is an associate professor of management. Zev J. Eigen, J.D., is an associate with Littler Mendelson in San Francisco. Michael Heise, J.D. Ph.D., is a professor of law at Case Western Reserve University School of Law. A graduate of the Cornell University School of Hotel Adiministration, Jenn Walwyn is a law student at the University of California, Los Angeles.

(C) 2001, Cornell University; an invited paper 